\title{
Highly Efficient Visible Light Active Doped ZnO Photocatalysts for the Treatment of Wastewater Contaminated with Dyes and Pathogens of Emerging Concern
}

\author{
Saima Aftab ${ }^{1}$, Tayyaba Shabir ${ }^{2}$, Afzal Shah ${ }^{1, * \mathbb{D}}$, Jan Nisar ${ }^{3}$, Iltaf Shah ${ }^{4} * \mathbb{D}$, Haji Muhammad 5 \\ and Noor S. Shah ${ }^{6}$
}

check for updates

Citation: Aftab, S.; Shabir, T.; Shah,

A.; Nisar, J.; Shah, I.; Muhammad, H.; Shah, N.S. Highly Efficient Visible Light Active Doped $\mathrm{ZnO}$ Photocatalysts for the Treatment of Wastewater Contaminated with Dyes and Pathogens of Emerging Concern. Nanomaterials 2022, 12, 486. https:// doi.org/10.3390/nano12030486

Academic Editors: George Z. Kyzas and Justo Lobato

Received: 5 January 2022

Accepted: 24 January 2022

Published: 29 January 2022

Publisher's Note: MDPI stays neutral with regard to jurisdictional claims in published maps and institutional affiliations.

Copyright: (c) 2022 by the authors. Licensee MDPI, Basel, Switzerland. This article is an open access article distributed under the terms and conditions of the Creative Commons Attribution (CC BY) license (https:// creativecommons.org/licenses/by/ $4.0 /)$.
1 Department of Chemistry, Quaid-i-Azam University, Islamabad 45320, Pakistan; saimaaftab2013@gmail.com 2 Department of Chemistry, Women University Multan, Multan 60000, Pakistan; tayyabashabir01@gmail.com

3 National Centre of Excellence in Physical Chemistry, University of Peshawar, Peshawar 25120, Pakistan; pashkalawati@gmail.com

4 Department of Chemistry, College of Science, United Arab Emirates University, Al Ain P.O. Box 15551, United Arab Emirates

5 Department of Chemistry, Federal Urdu University of Arts, Sciences and Technology, Karachi 75300, Pakistan; mhaji21@yahoo.com

6 Department of Environmental Sciences, COMSATS University Islamabad, Vehari Campus, Vehari 61100, Pakistan; samadchemistry@gmail.com

* Correspondence: afzals_qau@yahoo.com or afzalshah@qau.edu.pk (A.S.); altafshah@uaeu.ac.ae (I.S.)

\begin{abstract}
Water is obligatory for sustaining life on Earth. About 71\% of the Earth's surface is covered in water. However, only one percent of the total water is drinkable. The presence of contaminants in wastewater, surface water, groundwater, and drinking water is a serious threat to human and environmental health. Their toxic effects and resistance towards conventional water treatment methods have compelled the scientific community to search for an environmentally friendly method that could efficiently degrade toxic contaminants. In this regard, visible light active photocatalysts have proved to be efficient in eliminating a wide variety of water toxins. A plethora of research activities have been carried out and significant amounts of funds are spent on the monitoring and removal of water contaminants, but relatively little attention has been paid to the degradation of persistent water pollutants. In this regard, nanoparticles of doped $\mathrm{ZnO}$ are preferred options owing to their low recombination rate and excellent photocatalytic and antimicrobial activity under irradiation of solar light. The current article presents the roles of these nanomaterials for wastewater treatment from pollutants of emerging concern.
\end{abstract}

Keywords: visible light active photocatalyst; doped $\mathrm{ZnO}$; water contaminants; wastewater treatment; antimicrobial activity

\section{Introduction}

Semiconducting nanomaterials have received the utmost attention of researchers owing to their applicability in electronic devices, solar energy harvesting devices, drug delivery, water purification, pharmaceutical industries, biosensors, and ceramics $[1,2]$. Among nanomaterials, $\mathrm{ZnO}$ is of special interest for researchers thanks to its environmentally benign nature. Its band gap is $3.4 \mathrm{eV}$ and it is commonly doped with elements of group $\mathrm{I}$ and $\mathrm{V}$ in an attempt to make p-type $\mathrm{ZnO}$ for use as a visible light active photocatalyst. The literature survey reveals that oxygen deficient sites, Zn centres, and hydrogen bond ability facilitate electron doping in $\mathrm{ZnO}$ [3-7]. Doped zinc oxides are used as visible light active photocatalysts for the degradation of emerging pollutants (EPs), which demand special attention owing to their health hazardous effects.

More than seven-hundred EPs have been reported so for. They are natural or synthetic compounds that adversely affect the human health and environment. Emerging pollutants 
include fungicides, pharmaceuticals, personal care products, industrial supplements, and so on. The fate and transit of developing pollutants in the environment, as well as their toxicological effects, are poorly understood [8,9]. Hence, further investigations are required for Eps' elimination or their conversion to less harmful or nontoxic compounds. In this regard, photocatalysts are the subject of extensive investigations owing to their ability of degrading, detoxifying, or rendering the contaminants harmless. Semiconducting photocatalysts produce electron-hole pairs by the absorption of band gap matching photon. The resulting electron-hole pairs start a complex chain of reactions on the semi conductor's surface that leads to the degradation of contaminants adsorbed on the surface of semiconductor $[10,11]$.

Zinc oxide is photoactive and its photoactivity is further enhanced by doping. The empty octahedral sites in the hexagonal closed packed structure of zinc oxide generate interstitial gaps that are occupied by other atoms or defects. These imperfections add to zinc oxide's photocatalytic activity [12]. A variety of methods such as sol-gel, hydrothermal, spray pyrolysis, microwave-assisted procedure, chemical vapour deposition, ultrasonic condition, and precipitation approaches are used for the synthesis of zinc oxide. Compared with chemical methods, biological methods of its synthesis are gaining more popularity because they are simpler, cheaper, and safer $[13,14]$.

Doping of $\mathrm{ZnO}$ is done to lower its band gap so that it can absorb visible light, which constitutes $40-45 \%$ of sunlight. Doping also alters the electronic and optical characteristics of photocatalysts [15]. Hence, doped zinc oxide is used in various fields, from tyres to clay, medicines to agriculture, and paint to chemicals [16,17]. The resilience of $\mathrm{ZnO}$ to high energy radiations implies its entrenchment for space utilization, the tendency of $\mathrm{ZnO}$ to etch in acidic or basic solutions implying its suitability for manufacturing smaller devices, and its sensitivity to chemical species are additional appealing properties [18,19]. Moreover, $\mathrm{ZnO}$ has been proven as an effective photocatalyst for the degradation of various pollutants [20-22]. Its photocatalytic activity is further increased by quantum confinement effect by tuning the electron energy band gap. Although a few reviews on visible light active photocatalysts are available, a review of recent reports is always needed to update the readers about this research field. Moreover, in comparison with previous review articles focused on various pollutants, the present review is particularly dedicated to the removal of highly hazardous pollutants of emerging concern using doped zinc oxides as potential photocatalysts. To the best of our knowledge, this is the first report on doped zinc oxides nanomaterials that target the elimination of extremely toxic dyes and pathogens from water, and thus hold promise for protecting ecological and human health.

\section{Structure and Properties of $\mathrm{ZnO}$}

Crystallized $\mathrm{ZnO}$ in wurtzite hexagonal lattice form possesses oxygen ions in the tightest hexagonal packing. The tetrahedral locations are occupied by zinc ions (Figure 1). On the hexagonal side, or c axis, the spacing between close neighbours is slightly smaller than the other three. Although the interaction is polar according to the $\mathrm{c}$ axis, there is a homopolar component of binding between zinc and oxygen ions [23].

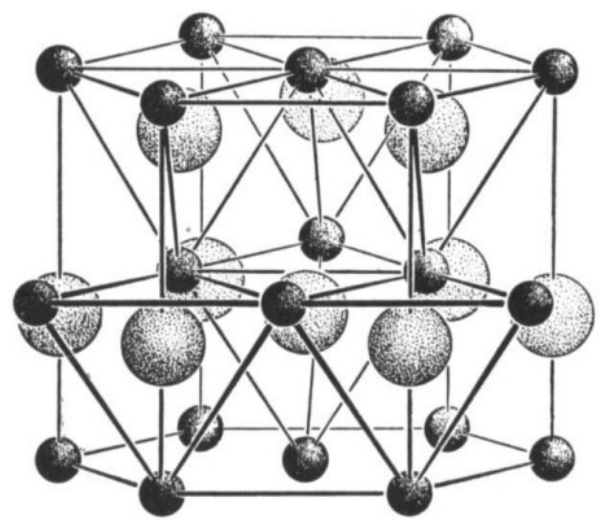

Figure 1. The wurtzite lattice of zinc oxide. Adapted with permission from [23]. Copyright 1959, Elsevier. 


\section{Visible Light Active (VLA) ZnO Photocatalysts}

The development of VLA photocatalysts to challenge water contamination is attracting the attention of researchers, because visible light makes up a significant fraction of the solar spectrum. Accordingly, many new photocatalytic materials have been recently developed to disinfect water. $\mathrm{ZnO}$ NPs is one of these materials, thanks to its excellent quantum efficiency and electrical structure that prevents the chances of recombination of electrons/charge in the electrolyte. Accordingly, many new doped $\mathrm{ZnO}$-based photocatalytic materials have been developed for disinfecting water. The band width of $\mathrm{ZnO}$ is altered with defects like doping with non-metals and metals [24]. Figure 2 indicates the general characteristics of dopants to increase the photoactivity of $\mathrm{ZnO}$ nanoparticles in the presence of visible-light.

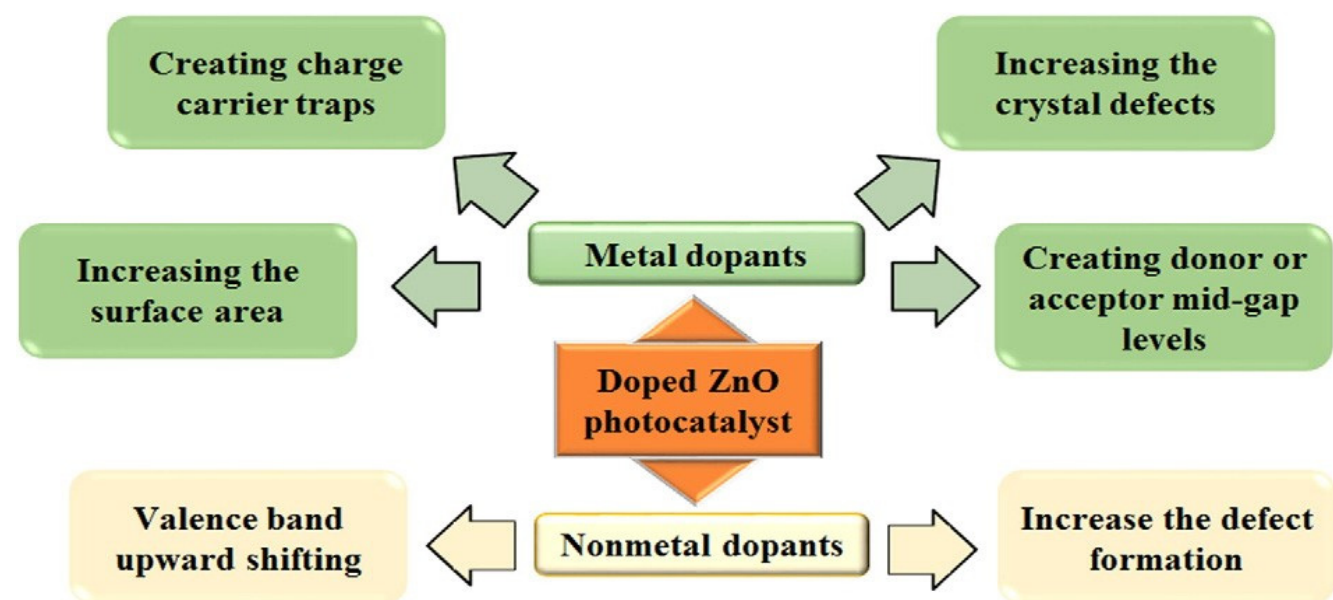

Figure 2. General properties of dopants for increasing the visible-light photocatalytics of $\mathrm{ZnO}$. Adapted with permission from [24]. Copyright 2016, Elsevier.

The objective of reducing the band gap of $\mathrm{ZnO}$ is to make the device work in the visible light range. There can be a decrease in the band width and activation under visible light by producing new energy levels within the band gap. By combining components, the band gap can be narrowed and, within the band gap, structural inadequacies lead to new levels of energy [25]. This has been depicted in Figure 3 by a simplified illustration where donor levels are introduced owing to the hydrogenation of zinc oxide microstructures within the gap between bands.

\section{Conduction Band CB}

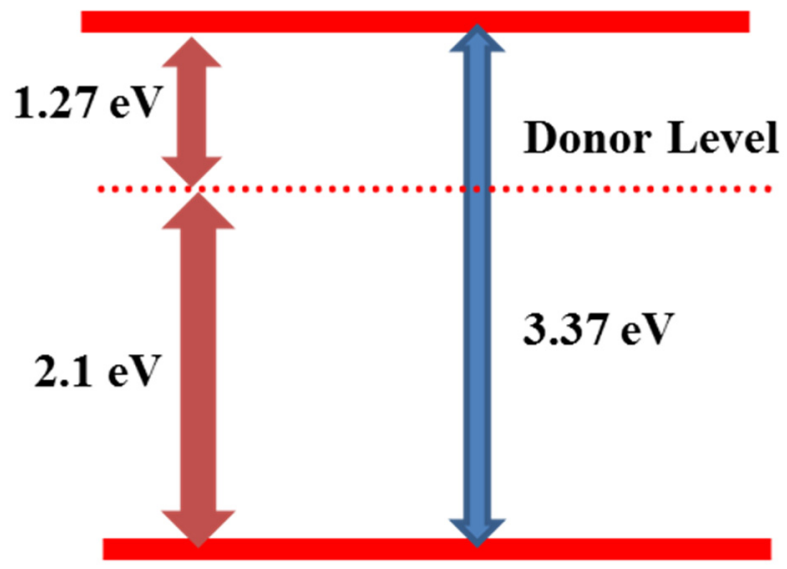

\section{Valence Band VB}

Figure 3. Diagram indicating the introduction of new energy levels inside the band gap of $\mathrm{ZnO}$. Adapted with permission from [25]. Copyright 2019, KeAi Publishing. 
$\mathrm{ZnO}$ NPs doped with non-metals have emerged as excellent materials owing to greater photocatalytic activity under solar light and a low recombination rate [26]. By incorporating additional components such as $\mathrm{S}, \mathrm{F}$, and $\mathrm{N}$, it is possible to minimize the band gap in $\mathrm{ZnO}[27,28]$. Figure 4 a shows the valence band (VB) of pure zinc oxide, which generally consists of $\mathrm{O} 2 \mathrm{~s}, \mathrm{O} 2 \mathrm{p}$, and $\mathrm{Zn} 3 \mathrm{p}$ states, whereas $\mathrm{O} 2 \mathrm{p}, \mathrm{Zn} 4 \mathrm{~s}$, and $\mathrm{Zn} 3$ s states dominate the conduction band. The fermi levels set to zero are shown by the dotted line. Figure $4 \mathrm{~b}$ demonstrates the direct band gap of zinc oxide, where the CB minima and VB maxima are both located at the same symmetric gamma $G$ point. The $C B$ minima and VB maxima are placed at the equivalent symmetric gamma $G$ point, which show direct bandgap properties of $\mathrm{ZnO}$. Furthermore, these non-metallic dopants of $\mathrm{C}$ and $\mathrm{P}$ have little impact on the lattice constant $\left(6.58 \mathrm{~A}^{\circ}\right)$ of $\mathrm{ZnO}$, which changes to 6.60 in the case of $\mathrm{C}$ doping and 6.62 in the case of $P$ doping. The conduction band changes to a lower energy in comparison with pure $\mathrm{ZnO}$ [29]. Incorporation of $\mathrm{B}$ and $\mathrm{F}$ in $\mathrm{ZnO}$ has been reported to increase the electrical properties [30].

(a)
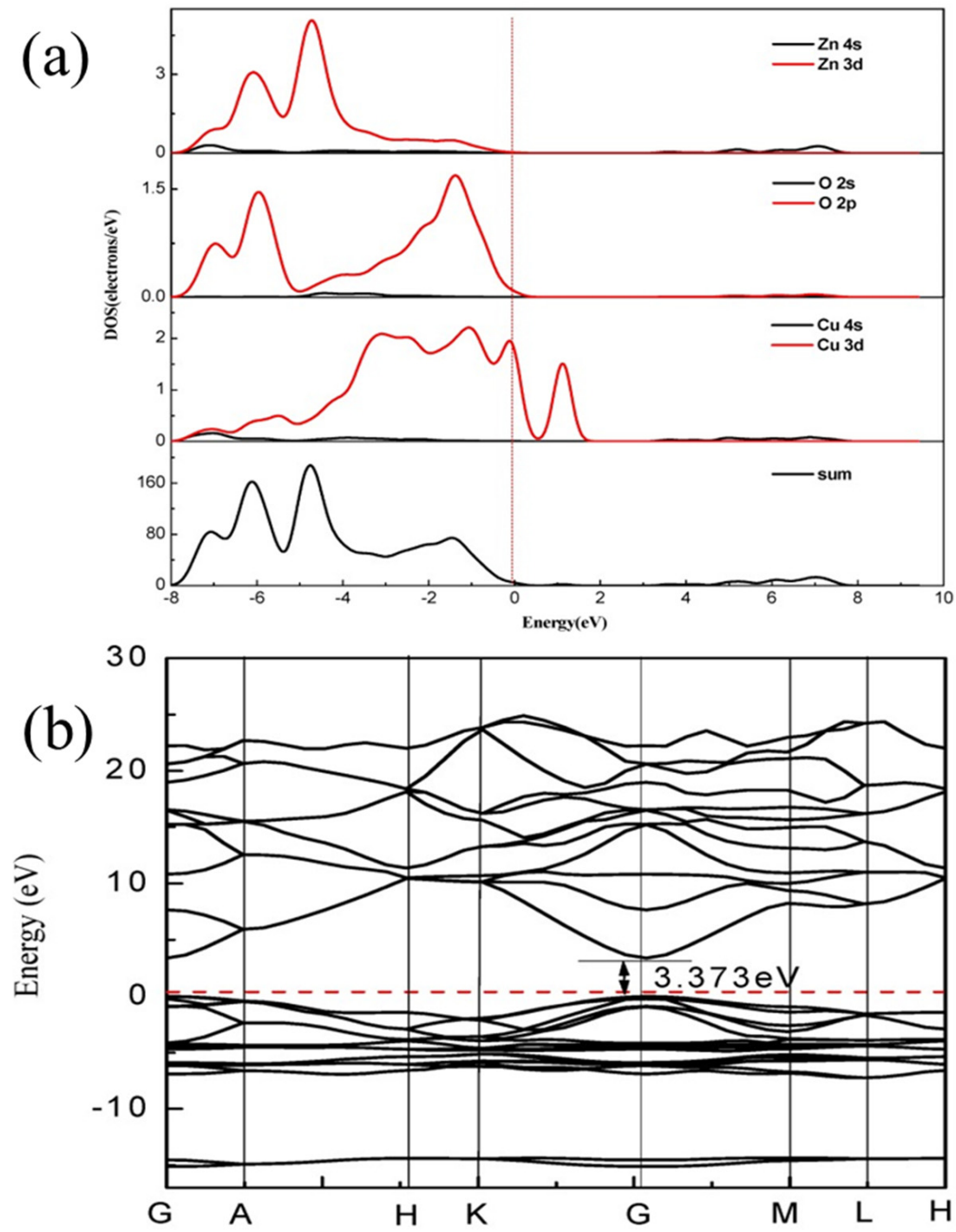

Figure 4. (a) Total density of state and (b) electronic band structure of pure ZnO reproduced from [29].

Nitrogen is considered as the most effective dopant for p-type $\mathrm{ZnO}$. However, obtaining consistent and stable p-type doping poses significant difficulties. For instance, there is no way to compensate the indigenous handicap caused by the usage of n-type doping. Research on doping $\mathrm{N}$ and $\mathrm{N}_{2}$ in $\mathrm{ZnO}$ has revealed that $\mathrm{N}_{2}$ at the $\mathrm{Zn}$ site acts as a shallow recipient, and at the $\mathrm{O}$-site, it acts as a donor, while $\mathrm{N}$ acts as a deep recipient [31-34]. A 
number of methods such as molecular beam epitaxy, active sputtering, chemical fumes, and $\mathrm{ZnO}$ ammonolysis at low temperatures are used for producing nitrogen-doped $\mathrm{ZnO}$. Using the proper nitrogen supply and promoting nitrogen introduction into oxide using a solution combustion method is a simple, yet promising method of nitrogen fixation in oxide [35]. N-doping in $\mathrm{ZnO}$ causes narrowing of the band gap in $\mathrm{ZnO}$ and increases the absorption of visible light [36,37]. The photocatalytic activity of $\mathrm{ZnO}$ towards the breakdown of organic dyes is increased by enhanced VL absorption, which is ascribed to the formation of localized states of $\mathrm{N} 2 \mathrm{p}$ in the bandgap [38].

\section{Use of $\mathrm{ZnO}$ for the Breakdown of Dyes}

Zinc oxide is extensively used for the breakdown of potentially harmful water pollutants. The majority of commonly used water treatment methods such as chemical treatment, adsorption, and membrane filtration are useful, but inadequate for complete removal of pollutants from wastewater [39]. Additionally, these approaches produce by-products such as sludge as solid waste and toxic gases that need further treatment. Therefore, for effective water clean-up, visible light active zinc-oxide-based photocatalysis is receiving special attention. Photocatalysis uses photoexcited charge carriers for the breakdown of organic contaminants. The photoactivity of $\mathrm{ZnO}$ is utilized for destroying such water toxins [40].

Shinde et al. [41] investigated two methods of dye degradation. In one method, the transport of electron into $\mathrm{CB}$ of photocatalyst occurs by photon having energy equal to or greater than the band gap of nanoparticles. The excited electrons result in the formation of holes in valence band. The generated electrons and holes leads to free radical formation [42]. The oxidation of pigments is triggered by the holes present in the valence band.

$$
\mathrm{h}^{+} \mathrm{VB}+\text { dye } \rightarrow \text { dye }{ }^{*} \rightarrow \text { dye degradation }
$$

The second method involves dye sensitization, where dye on the water surface absorbs visible radiation. The absorbed photon excites electrons of dye molecules from HOMO to LUMO. The electron present in LUMO shifts to the conduction band of $\mathrm{ZnO}$. On reaction with $\mathrm{O}_{2}$, this electron yields $\mathrm{O}_{2}{ }^{-}$, which causes the breakdown of pollutants present in water. The schematics of both methods can be seen in Figure 5.

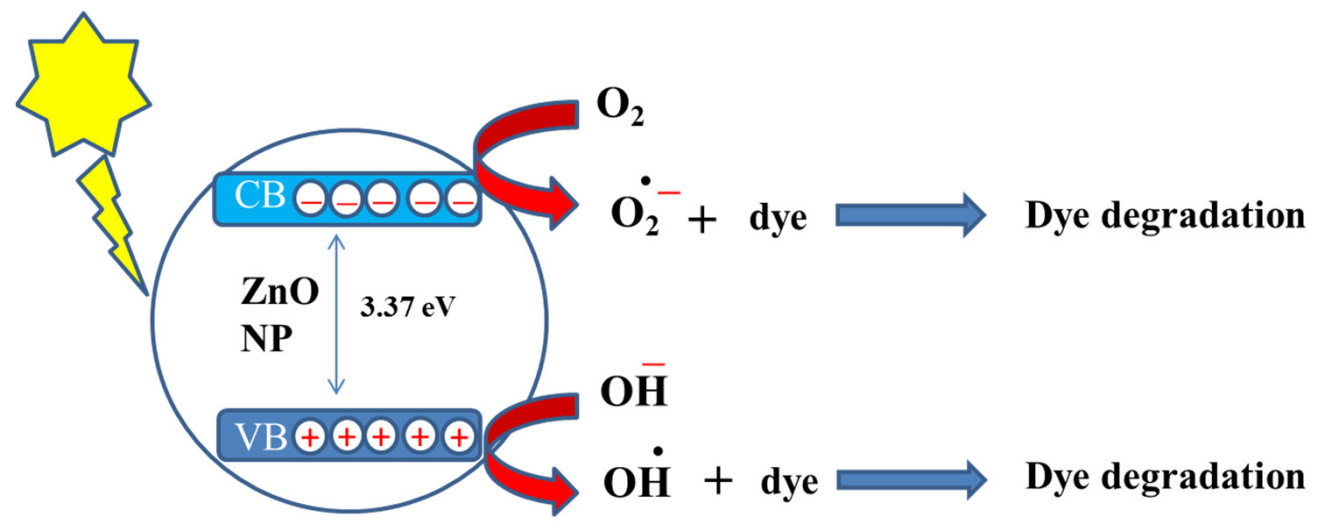

Figure 5. Schematics of the photoexcitation of the dye followed by its photocatalytic degradation under solar irradiation.

T. Bora et al. [43] reported the potential antibacterial activity of $\mathrm{ZnO}$ nanorods and their photocatalytic activity towards the breakdown of methylene blue and phenol (Figure 6). The rate constant for photocatalytic breakdown of methylene blue dye and phenol was found to be 0.032 and $0.094 \mathrm{~min}^{-1}$, respectively, at $250{ }^{\circ} \mathrm{C}$. Similarly, ZnO doped with Ag degrades organic dyes by the prevention of hole and electron recombination, which enhances the photocatalytic activity, as expected [44]. The degradation efficiency of $\mathrm{ZnO}$ doped with silver was found to be $99.64 \%$ against rhodamine B. 


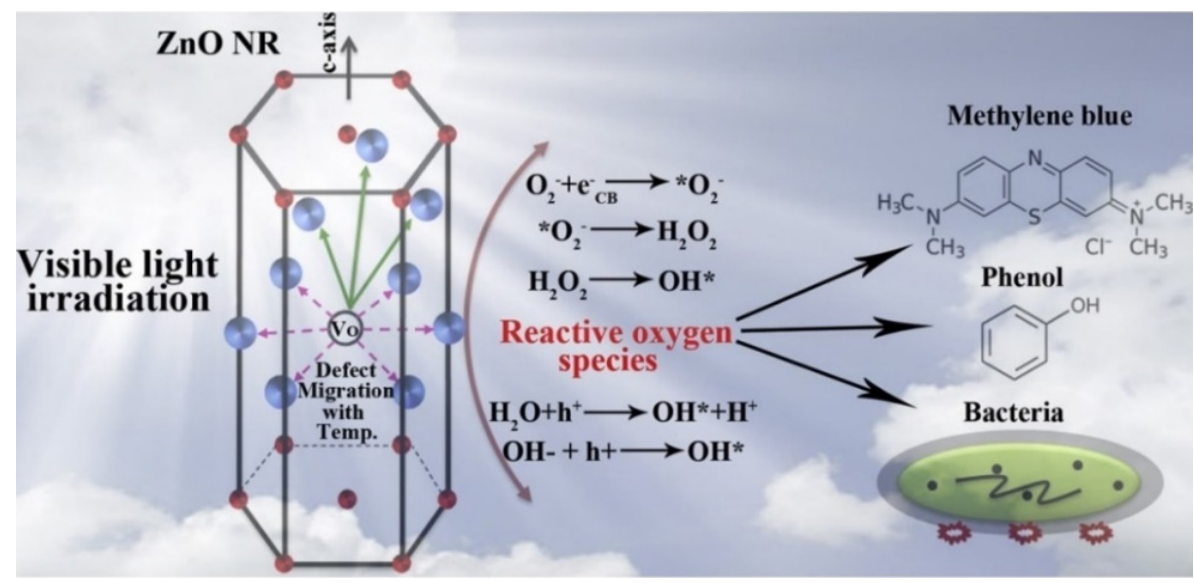

Figure 6. Mechanism of antibacterial and photocatalytic activity of $\mathrm{ZnO}$ nanorods. Adapted with permission from [43]. Copyright 2017, Elsevier.

Kumar et al. [45] also discovered that the photocatalytic activity of $\mathrm{ZnO}$ is increased on doping with Ag. Nanoparticles of Ag-ZnO developed with 0.02, 0.04, and 0.06 percent of Ag showed $3.03 \mathrm{eV}, 3.01 \mathrm{eV}$, and $2.96 \mathrm{eV}$ band gaps, respectively. As discussed earlier, doping lowers the energy required to shift an electron from valence band to conduction band [46]. William et al. [47] used Ag-doped $\mathrm{ZnO}$ thin film for the degradation of methylene blue. The results of their experiments revealed that silver-doped $\mathrm{ZnO}$ degrades dye more effectively $(45.1 \%)$ than a pure $\mathrm{ZnO}(2.7 \%)$ film under irradiation of VL. In the same area of study, Sabry et al. [48] carried out some modification in Ag-doped $\mathrm{ZnO}$ nanostructure by introducing stearic acid for the breakdown of methylene blue and achieved $93 \%$ breakdown efficiency after $80 \mathrm{~min}$ exposure to visible light. Liu et al. [49] also used doped Ag- $\mathrm{ZnO}$ and found it to be effective for the degradation of Congo Red. Figure 7 presents the optical properties of doped $\mathrm{ZnO}$ by photoluminescence and UV/Vis absorption spectroscopy. Using the $\mathrm{W}$ Xe lamp, Congo Red, Methyl Orange, and Methylene Blue were photocatalytically broken down. A $0.25 \mathrm{M} \mathrm{Ag-doped} \mathrm{ZnO}$ showed maximum photocatalytic activity of $91.9 \%$ in 120 min under a solar light simulator.

Saffari et al. [50] prepared pure $\mathrm{ZnO}$ and P-containing $\mathrm{ZnO}$ for Rhodamine B degradation. Using a halogen lamp, visible light in the wavelength range of 375-1000 nm was employed. A lowering in the electrons and holes recombination rate in the sample containing $1.8 \%$ of phosphorus resulted in complete breakdown of RhB dye in $180 \mathrm{~min}$. Kuriakose et al. [51] applied $\mathrm{Cu}$-doped $\mathrm{ZnO}$ for the degradation of methyl orange and methylene blue dyes. Furthermore, 5\% Cu doping in $\mathrm{ZnO}$ led to $92 \%$ and $80 \%$ degradation of methylene blue and methyl orange, respectively, in $30 \mathrm{~min}$. Vaiano et al. [52] used $\mathrm{ZnO}$ doped with $\mathrm{Cu}$ for photocatalytic oxidation of As (III) to As (V). Here, $52 \%$ photocatalysis was observed after VL exposure of $180 \mathrm{~min}$ for $\mathrm{ZnO}$ doped with $1.08 \%$ of $\mathrm{Cu}$. Similarly, Kamlesh et al. [53] employed $\mathrm{Cu}$-doped $\mathrm{ZnO}$ nanoparticles for methyl green degradation and, under irradiation of $\mathrm{VL}$, noticed a 3.5 -fold enhancement in photocatalytic activity against methyl green as compared with undoped $\mathrm{ZnO}$.

Vinodkumar et al. [54] studied the impact of Mg doping on the photocatalytic performance of $\mathrm{ZnO}$. Compared with $\mathrm{ZnO}, 0.1 \% \mathrm{MgZnO}$ showed a twofold higher photocatalytic efficiency. Adam et al. [55] also synthesized $\mathrm{Mg}$-doped $\mathrm{ZnO}$ nanoparticles and investigated their role for the degradation of methylene blue. $\mathrm{ZnO}$ on doping with $0,3,5$, and $7 \%$ of $\mathrm{Mg}$ resulted in approximately 55, 65, 77, and 96\% decolouration of MB dye, respectively. The improved photocatalytic performance by $\mathrm{Mg}$-doped $\mathrm{ZnO}$ can be attributed to the role of $\mathrm{Mg}$ in the $\mathrm{ZnO}$ lattice that enhances the hydroxyl ions' absorption at the nanoparticle surface and works as trap sites to increase the photodegradation as well as to lower the electron-hole pair recombination. Adeel et al. [56] investigated $\mathrm{ZnO}$ doped with Co to remove methyl orange from wastewater. Figure 8 shows that $\mathrm{ZnO}$ doped with $10 \% \mathrm{Co}$ 
causes $93 \%$ methyl orange degradation. The authors ascribed the increase in photocatalysis to the prevention of electron-hole recombination.
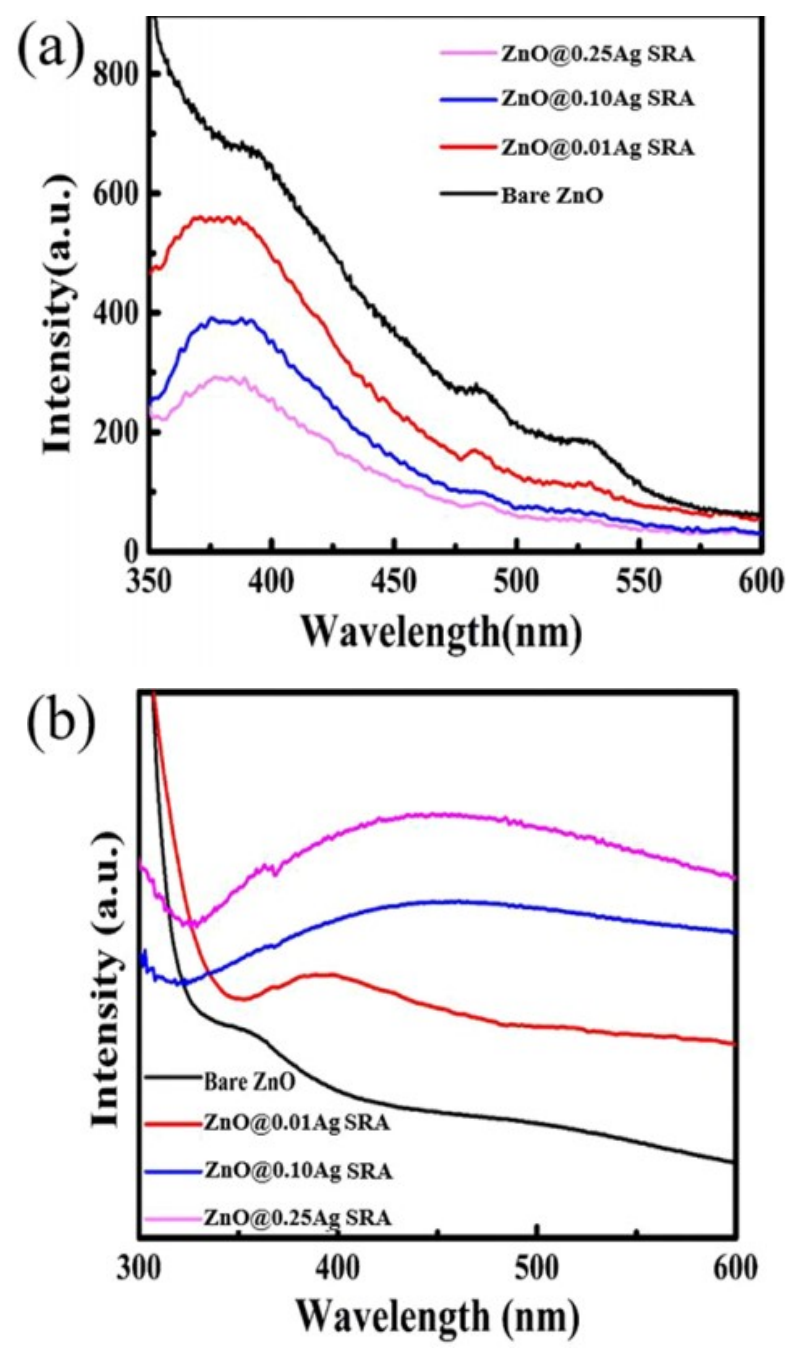

Figure 7. (a) Room temperature PL spectra of samples synthesized by electrolytes containing different concentrations of $\mathrm{Ag}^{+}$. (b) UV/Vis absorption spectra of bare $\mathrm{ZnO}$ and $\mathrm{Ag}-\mathrm{ZnO}$ submicrometer rods. Adapted with permission from [49]. Copyright 2019, ACS.

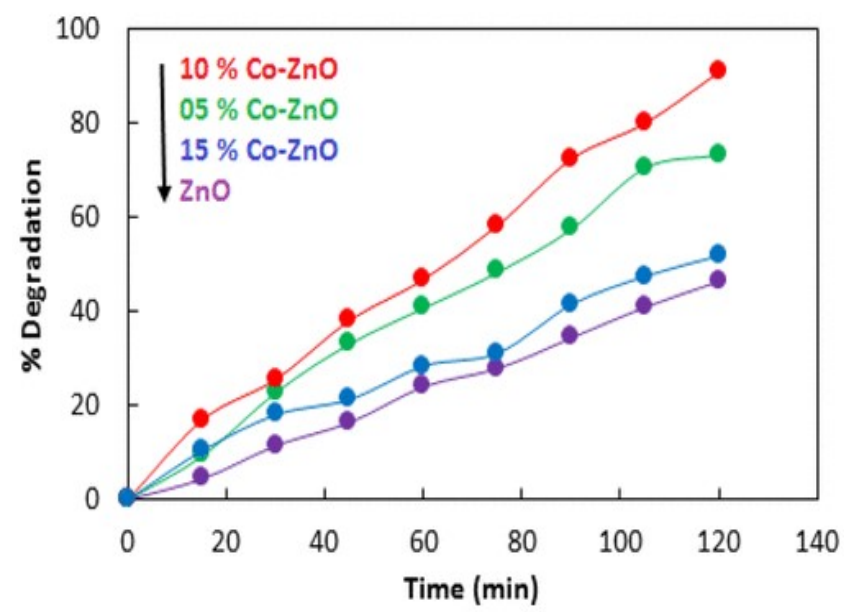

Figure 8. Photodegradation of methyl orange with pure $\mathrm{ZnO}$ and doped $\mathrm{ZnO}$ with $5 \% \mathrm{Co}, 10 \%$ Co, and $15 \%$ Co. Adapted with permission from [56]. Copyright 2019, ACS. 
Hernandez et al. [57] compared the photocatalytic efficiency of undoped and Eu doped $\mathrm{ZnO}$. A 99.3\% breakdown of methylene blue dye was achieved with doped nanoparticles. Similary, Tb- and Eu-doped ZnO NPs showed 100\% photodegradation of methylene blue and facilitated reduction of $\mathrm{CO}_{2}$ and production of $\mathrm{H}_{2}$ [58]. Petronela et al. [59] synthesized Ni-Co codoped ZnO NPs to check their efficiency towards the removal of Rhodamine B dye from contaminated water in the presence of visible light, which was found to be $42 \%$ for $0.69 \%$ of both of the dopants. Similarly, Shanmugam et al. [60] probed the photocatalysis of $\mathrm{ZnO} / \mathrm{Cu} / \mathrm{Sn}$ nanoparticles and found these to have much better photocatalytic activity towards methylene blue, which was completely degraded in 180 min under visible light irradiation.

Qin et al. [61] observed the ability of ZnO-graphene nanocomposites for the removal of methylene blue from wastewater. High absorptivity of the dye and charge separation process led to enhanced photocatalytic degradation efficiency of the nanocomposites. Ruhullah et al. [62] prepared Mn-doped $\mathrm{ZnO}$ and found these to be effective for the breakdown of basic aniline dye and methylene blue dye. In another study, carbon nanotubes supported Mn-doped ZnO NPs efficiently photodegraded $>95 \%$ malachite green in water under irradation of VL [63]. Similarly, Labhne et al. reported photodegradation of rhodamine B (99\% in $140 \mathrm{~min}$ ) and congo red (100\% in $160 \mathrm{~min}$ ) using Mn-doped $\mathrm{ZnO}$ supported with reduced graphene [64]. Maline Ghosh et al. [65] used a bimetallic photocatalyst, which resulted in $90 \%$ breakdown of caffeine with a rate constant of $0.024 \mathrm{~min}^{-1}$. Subhan et al. [66] prepared a trimetallic oxide nanocomposite $\mathrm{ZnO} \cdot \mathrm{CuO} \cdot \mathrm{CeO}_{2}$, which exhibited $97 \%$ photocatalytic dye degradation activity. $\mathrm{ZnO}$ nanorods doped with $\mathrm{Nd}$ and $\mathrm{Gd}$ were also reported for methylene blue degradation under illumination of VL. A $1.5 \% \mathrm{Nd}-\mathrm{Gd}$ codoped $\mathrm{ZnO}$ resulted in $93 \%$ photocatalytic breakdown of $\mathrm{MB}$ in $180 \mathrm{~min}$ [67]. The photocatalytic efficiency of other doped zinc oxides for the degradation of various dyes can be seen in Table 1 [68-77]. Thus, it can be concluded that doping increases the photocatalytic characteristics of $\mathrm{ZnO}$ nanostructures.

Table 1. Percentage degradation of various dyes using doped $\mathrm{ZnO}$ photocatalysts.

\begin{tabular}{|c|c|c|c|c|c|}
\hline Sr. No. & Doped ZnO & Pollutants & $\%$ Degradation & Light Source & References \\
\hline 1. & $\mathrm{Sn} / \mathrm{ZnO}$ & Methyl blue dye & 81 & $150 \mathrm{~W}$ Xe lamp & [68] \\
\hline 2. & $\mathrm{La} / \mathrm{ZnO}$ & Methyl orange dye & 85.86 & Visible light & [69] \\
\hline 3. & $\mathrm{Ir} / \mathrm{ZnO}$ & Malachite green & $>90$ & $9 \mathrm{~W}$ fluorescent visible lamp & [70] \\
\hline 4. & $\mathrm{Sr} / \mathrm{ZnO}$ & Methylene blue & 50 & $500 \mathrm{~W}$ Xe lamp & [71] \\
\hline 5. & $\mathrm{~V} / \mathrm{ZnO}$ & Malachite green & $>99$ & Osram Lumilux daylight lamp & [72] \\
\hline 6. & $\mathrm{Co} / \mathrm{ZnO}$ & Methylene blue & 98 & $\% 500 \mathrm{~W}$ halogen lamp & [73] \\
\hline 7. & $\mathrm{Cu} / \mathrm{ZnO}$ & Direct blue 15 dye & 70 & Visible light & [74] \\
\hline 8. & $\mathrm{Ag} / \mathrm{ZnO}$ & Cibacron brilliant yellow 3G-B & 65 & $400 \mathrm{~mW} \cdot \mathrm{cm}^{-2}$ Xe lamp & [75] \\
\hline 9. & $\mathrm{Al} / \mathrm{ZnO}$ & Naphthol green B & 100 & $25 \mathrm{~W} \cdot \mathrm{cm}^{-2}$ sunlight & {$[76]$} \\
\hline 10. & $\mathrm{Nd} / \mathrm{ZnO}$ & Congo red & 93.7 & Visible light & [77] \\
\hline
\end{tabular}

\section{Water Disinfection with Visible Light Active ZnO-Based Photocatalysts}

Booming industrialization has led to water quality deterioration. Chlorination and ozonization methods are frequently used for disinfecting water. However, these methods are not free from limitations; for example, various carcinogenic by-products are produced during chlorination and ozonization [78-80]. Photocatalysts hold great promise for effectively treating contaminated water. Among the photocatalysts, $\mathrm{ZnO}$ has received enormous attention as a disinfectant thanks to its stable nature under severe processing environments [81]. Moreover, it does not cause secondary pollution. Its phase composition, particle size distribution, defective surface, and specific surface area play their role in antibacterial/antimicrobial activity. $\mathrm{ZnO}$ nanoparticles adopt different ways for their antimicrobial 
activity, such as release of oxygen species and $\mathrm{Zn}^{2+}$, which can kill microorganisms by damaging their DNA and cell membrane. $\mathrm{ZnO}$ also exerts antimicrobial activity when it comes in direct contact with the cell membrane of microbes [81-84]. Gancheva and colleagues [85] utilized zinc oxide powder for disinfecting water. The azo dye of Malachite Green was removed from water in 180 min using $\mathrm{ZnO}$ powder in the presence of visible light during the disinfection procedure. Mahamuni et al. [86] found that $\mathrm{ZnO}$ particles had varying degrees of antibiofilm and antibacterial action against Gram-negative and Gram-positive Staphylococcus and Proteus vulagaris. The antibacterial and antibiofilm activity of $\mathrm{ZnO}$ nanoparticles was found to vary inversely with particle size. At a concentration of about $50 \mu \mathrm{g} / \mathrm{mL}$, it inhibited 32.67 percent of Staphylococcus aureus and 22.38 percent of Proteus vulgaris, respectively. The greatest biofilm resistance against Staphylococcus aureus and Proteus was 67.3 percent and 58.18 percent, respectively, for $250 \mu \mathrm{g} / \mathrm{mL}$ concentration of $\mathrm{ZnO}$. In one particular study, Haque et al. [87] reported that $\mathrm{ZnO}$ prepared by the biological method degraded methylene blue dye up to $80 \%$ in $20 \mathrm{~min}$, compared with 68 percent by $\mathrm{ZnO}$ produced by the sol-gel approach. So, according to this study, $\mathrm{ZnO}$ prepared by the biosynthetic approach outperforms $\mathrm{ZnO}$ prepared via the sol-gel method in terms of water disinfection. Working in this area, Ogunyemi, et al. [88] found the maximum antibacterial activity of ZnO NPs produced via using olive leaves compared with chamomile flower and red tomato fruit (Figure 9). Olea europaea $\mathrm{ZnONPs}$ had the maximum inhibitory zone of $2.2 \mathrm{~cm}$ at $16.0 \mu \mathrm{g} / \mathrm{mL}$. The authors attributed this excellent activity to the small crystallite size of $\mathrm{ZnO}$ NPs.

Similarly, J. Suresh et al. [89] also synthesized zinc oxide NPs in combination with Costus Pictus D. leaf extracts. Biosynthesized zinc oxide nanoparticles showed greater antimicrobial activity against fungal and bacterial species. The zone of inhibition for B. subtilis, S. aureus, S. paratyphi, and E. coli was found to be $17,10,12$, and $10 \mathrm{~mm}$, respectively. Inhibition and cell survival were found to increase with the increasing concentration of $\mathrm{ZnO}$ nanoparticles. Working in this area, Panchal et al. [90] mixed seed extract from Ocimum tenuiflorum to $\mathrm{Ag} / \mathrm{ZnO}$ NPs and observed improved antimicrobial activity in comparison with pure NPs and $\mathrm{Ag} / \mathrm{ZnO}$. In $15 \mathrm{~min}$, bacteria with a density of $1 \times 10^{8} \mathrm{cfu}$ were killed by $1.0 \% \mathrm{Ag} / \mathrm{ZnO}$ nanocomposite.

Weiwei He et al. studied the antibacterial activity of $\mathrm{Au} / \mathrm{ZnO}$ hybrid nanostructures [91] and found that deposition of gold nanoparticles in the molar ratio of $0.2 \%$ on $\mathrm{ZnO}$ surface significantly increased the antibacterial activity of $\mathrm{ZnO}$. $\mathrm{ZnO} / \mathrm{Au}$ nanostructures were found to be nearly three times more efficient than pure $\mathrm{ZnO}$ nanoparticles at killing E. coli. Similarly, doping $\mathrm{ZnO}$ with other nanoparticles such as $\mathrm{Ag}$, $\mathrm{Sn} \mathrm{TiO}_{2}$, and $\mathrm{Cu}$ also show improved properties. For instance, Shanmugam et al. [60] developed an $\mathrm{Sn} / \mathrm{Cu}$ doped $\mathrm{ZnO}$ photocatalyst and found that it completely removes methylene blue in $180 \mathrm{~min}$ under visible light. They found an increase in the photodegradation rate of doped $\mathrm{ZnO}$ in contrast to undoped $\mathrm{ZnO}$ by a factor of 2.6, and the photocatalyst showed good antibacterial activity against the pathogens E. coli and S. aureus (G+).

Qamar et al. [92] discovered the antimicrobial properties of hybrid g- $\mathrm{C}_{3} \mathrm{~N}_{4} / \mathrm{Cr}-\mathrm{ZnO}$ nanocomposite. These nanocomposites were found to cause $93 \%$ removal of methylene blue in $90 \mathrm{~min}$. The enhancement in photocatalysis of hybrid composite was due to good separation of electron and hole pairs and absorption. Good antibacterial activity of composites was observed against Gram-positive (Bacillus subtilis, Staphylococcus aureus, and Streptococcus salivarius) and Gram-negative (Escherichia coli) bacteria. The inhibition zone was found to be approximately $18,19,17$, and $15 \mathrm{~mm}$ for B. subtilis, S. aureus, S. salivarius, and E. coli, respectively. Munawar et al. [93] synthesized heterostructured nanocomposite $\mathrm{ZnO}-\mathrm{Er}_{2} \mathrm{O}_{3}-\mathrm{Yb}_{2} \mathrm{O}_{3}$, which demonstrated enhanced antibacterial activity against $E$. coli (Esherichia coli). The Fe/ZnO nanoparticles prepared by Das et al. photocatalytically disinfected multidrug-resistant $E$. Coli in true samples from a municipal tap, river, and pond. $\mathrm{Fe} / \mathrm{ZnO}$ nanoparticles were found to disinfect $E$. Coli completely in $90 \mathrm{~min}$ [94]. Li-doped ZnO NPs proved to be promising against E. faecalis, S. tyjimurium, and Esherichia coli [95]. Darwish and his group [96] reported the potential of $\mathrm{Sm} / \mathrm{Ag} / \mathrm{ZnO} /$ cuttlefish bone 
nanorods in destroying $S$. mansoni worms. The percentage inhibition was documented to be 20 and 47\% for P. aeruginosa and S. aureua, respectively. These literature findings depict that doped ZnO NPs endowed with photocatalytic and antimicrobial activity are ideal nanomaterials for water treatment and disinfection applications.

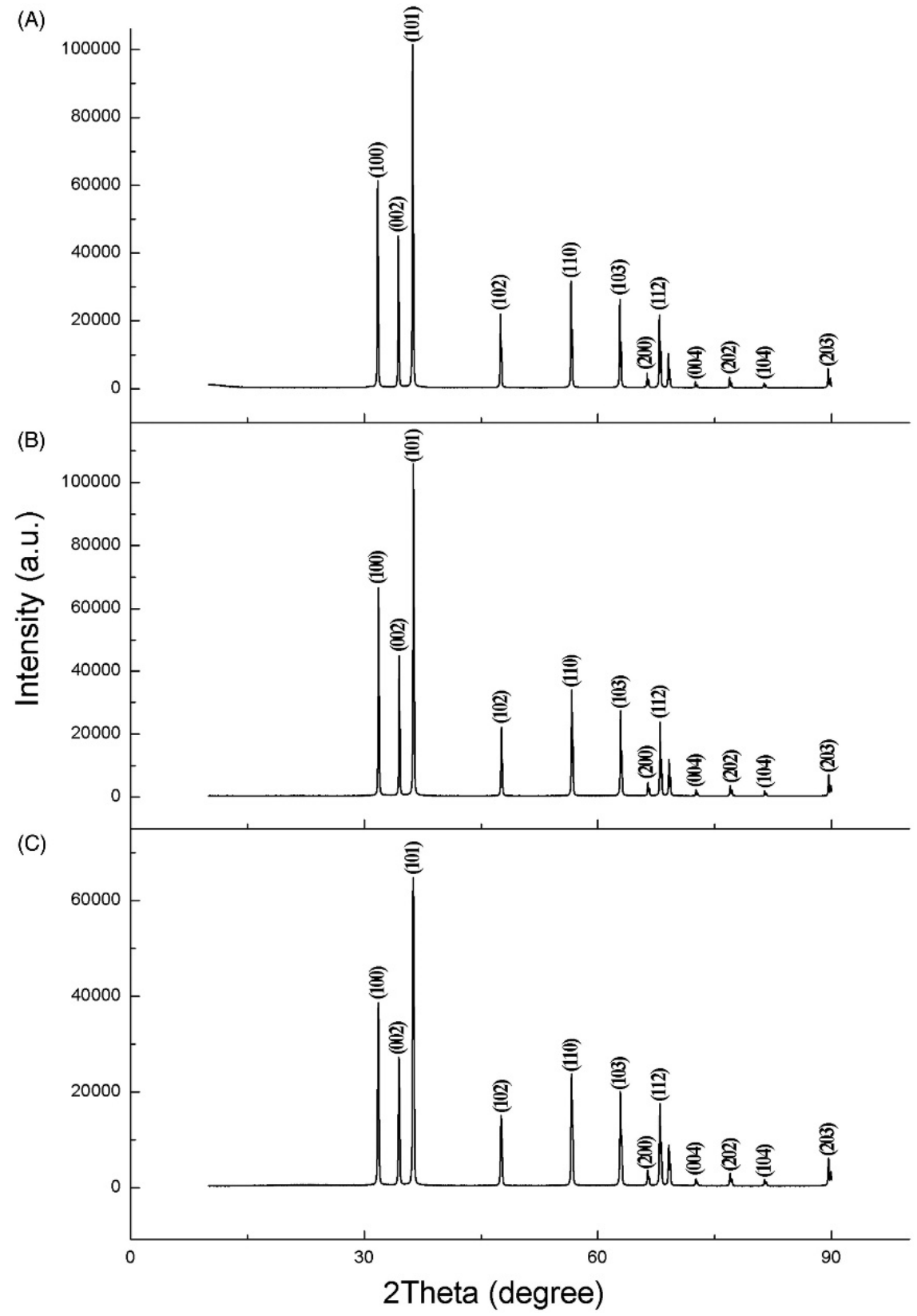

Figure 9. XRD spectra of synthesized zinc oxide nanoparticles using (A) olive leaves, (B) chamomile flower, and (C) red tomato fruit [88].

\section{Conclusions}

The presence of water toxins, especially dyes and pathogens, is challenging scientists to search for highly effective, cost affordable, and environmentally friendly methods for water purification. This driving force has led to remarkable scientific research in wastewater treatment. One of the environmentally friendly technologies for water treatment is the use of visible light active photocatalysts. In this regard, $\mathrm{ZnO}$ has been given special attention as it is nontoxic and its band gap is switched by earth abundant elements of group I and $\mathrm{V}$, making doped zinc oxides cost-effective and suitable for working under visible light, 
which is a major $(45 \%)$ portion of sunlight. The results presented in this document reveal the competency of doped zinc oxide for disinfecting water under visible light irradiation. Doping reduces the chances of electron and hole pairs' recombination and, consequently, their availability initiates free-radical-based degradation of water pollutants. The results reveal that the photocatalytic performance of doped $\mathrm{ZnO}$ depends on various factors such as the concentration of the dopant, their energy states within the $\mathrm{ZnO}$ lattice, localized states of dopants in the bandgap of $\mathrm{ZnO}$, dopants sites' distribution, electron hole pair recombination, and the intensity of incident light. $\mathrm{ZnO}$ nanomaterials have the ability to remove microbes and organic dyes from wastewater. The commercial application of doped $\mathrm{ZnO}$ nanoparticles can be anticipated in the near future owing to their nontoxic, low-cost, improved photocatalytic, and antimicrobial activity. The presented work targets the elimination of extremely toxic dyes and pathogens with the potential to remove them from water, thus protecting ecological and human health. However, highly efficient photocatalytic degradation and antimicrobial activity still demand more research to design more effective doped $\mathrm{ZnO}$ NPs and $\mathrm{ZnO}$-based nanocomposites. Future endeavors will be focused on beating the challenge of synthesizing doped $\mathrm{ZnOs}$ with a suitable bandgap. The selection of materials remains a vital consideration for achieving this future targeted objective.

Author Contributions: Conceptualization, A.S., I.S. and N.S.S.; methodology, S.A. and T.S.; software, S.A.; validation, A.S., J.N. and S.A.; formal analysis, T.S.; investigation, T.S.; resources, A.S.; data curation, J.N.; writing - original draft preparation, S.A. and T.S.; writing-review and editing, J.N., H.M. and N.S.S.; visualization, I.S.; supervision, A.S.; project administration, A.S. and J.N.; funding acquisition, I.S. and A.S. All authors have read and agreed to the published version of the manuscript.

Funding: Iltaf Shah graciously acknowledges the generous support of UAE University (SDG-Grant2022) and Afzal Shah gratefully acknowledges the support of Quaid-i-Azam University Islamabad.

Institutional Review Board Statement: Not relevant to our study.

Informed Consent Statement: Not applicable.

Data Availability Statement: Article was written in the light of all mentioned references.

Conflicts of Interest: The authors declare no conflict of interest.

\section{References}

1. Rahman, B.; Viphavakit, C.; Chitaree, R.; Ghosh, S.; Pathak, A.K.; Verma, S.; Sakda, N. Optical Fiber, Nanomaterial, and THz-Metasurface-Mediated Nano-Biosensors: A Review. Biosensors 2022, 12, 42. [CrossRef] [PubMed]

2. Zafar, N.; Madni, A.; Khalid, A.; Khan, T.; Kousar, R.; Naz, S.S.; Wahid, F. Pharmaceutical and Biomedical Applications of Green Synthesized Metal and Metal Oxide Nanoparticles. Curr. Pharm. Des. 2020, 26, 5844-5865. [CrossRef] [PubMed]

3. Annu, A.A.; Ahmed, S. Green synthesis of metal, metal oxide nanoparticles, and their various applications. Handb. Ecomater. 2018, 1-45. [CrossRef]

4. Musa, I.; Qamhieh, N. Study of optical energy gap and quantum confinement effects in zinc oxide nanoparticles and nanorods. Dig. J. Nanomater. Biostruct. 2019, 14, 119-125.

5. Kim, K.J.; Kreider, P.B.; Choi, C.; Chang, C.H.; Ahn, H.G. Visible-light-sensitive Na-doped p-type flower-like ZnO photocatalysts synthesized via a continuous flow microreactor. RSC Adv. 2013, 3, 12702-12710. [CrossRef]

6. Fortunato, E.; Gonçalves, A.; Pimentel, A.; Barquinha, P.; Gonçalves, G.; Pereira, L.; Ferreira, I.; Martins, R. Zinc oxide, a multifunctional material: From material to device applications. Appl. Phys. A 2009, 96, 197-205. [CrossRef]

7. Ates, T.; Tatar, C.; Yakuphanoglu, F. Preparation of semiconductor ZnO powders by sol-gel method: Humidity sensors. Sens. Actuators A Phys. 2013, 190, 153-160. [CrossRef]

8. Naidu, R.; Espana, V.A.A.; Liu, Y.; Jit, J. Emerging contaminants in the environment: Risk-based analysis for better management. Chemosphere 2016, 154, 350-357. [CrossRef]

9. Geissen, V.; Mol, H.; Klumpp, E.; Umlauf, G.; Nadal, M.; van der Ploeg, M.; van de Zee, S.E.; Ritsema, C.J. Emerging pollutants in the environment: A challenge for water resource management. Int. Soil Water Conserv. Res. 2015, 3, 57-65. [CrossRef]

10. Castellote, M.; Bengtsson, N. Principles of $\mathrm{TiO}_{2}$ photocatalysis. In Applications of Titanium Dioxide Photocatalysis to Construction Materials; Springer: Berlin/Heidelberg, Germany, 2011; pp. 5-10.

11. Xie, J.; Wang, H.; Duan, M.; Zhang, L. Synthesis and photocatalysis properties of ZnO structures with different morphologies via hydrothermal method. Appl. Surf. Sci. 2011, 257, 6358-6363. [CrossRef] 
12. Kajbafvala, A.; Ghorbani, H.; Paravar, A.; Samberg, J.P.; Kajbafvala, E.; Sadrnezhaad, S. Effects of morphology on photocatalytic performance of Zinc oxide nanostructures synthesized by rapid microwave irradiation methods. Superlattices Microstruct. 2012, 51,512-522. [CrossRef]

13. Fakhari, S.; Jamzad, M.; Fard, H.K. Green synthesis of zinc oxide nanoparticles: A comparison. Green Chem. Lett. Rev. 2019, 12, 19-24. [CrossRef]

14. Sangeetha, G.; Rajeshwari, S.; Venckatesh, R. Green synthesis of zinc oxide nanoparticles by aloe barbadensis miller leaf extract: Structure and optical properties. Mater. Res. Bull. 2011, 46, 2560-2566. [CrossRef]

15. Rekha, K.; Nirmala, M.; Nair, M.G.; Anukaliani, A. Structural, optical, photocatalytic and antibacterial activity of zinc oxide and manganese doped zinc oxide nanoparticles. Phys. B Condens. Matter 2010, 405, 3180-3185. [CrossRef]

16. Mustapha, S.; Ndamitso, M.M.; Abdulkareem, A.S.; Tijani, J.O.; Shuaib, D.T.; Ajala, A.O.; Mohammed, A.K. Application of TiO 2 and $\mathrm{ZnO}$ nanoparticles immobilized on clay in wastewater treatment: A review. Appl. Water Sci. 2020, 10, 49. [CrossRef]

17. Chakraborty, S.; Kumbhakar, P. Observation of exciton-phonon coupling and enhanced photoluminescence emission in ZnO nanotwins synthesized by a simple wet chemical approach. Mater. Lett. 2013, 100, 40-43. [CrossRef]

18. Gionco, C.; Fabbri, D.; Calza, P.; Paganini, M.C. Synthesis, characterization, and photocatalytic tests of N-doped zinc oxide: A new interesting photocatalyst. J. Nanomater. 2016, 2016, 4129864. [CrossRef]

19. Rodnyi, P.; Khodyuk, I. Optical and luminescence properties of zinc oxide. Opt. Spectrosc. 2011, 111, 776-785. [CrossRef]

20. Sorbiun, M.; Mehr, E.S.; Ramazani, A.; Fardood, S.T. Green synthesis of zinc oxide and copper oxide nanoparticles using aqueous extract of oak fruit hull (jaft) and comparing their photocatalytic degradation of basic violet 3. Int. J. Environ. Res. 2018, 12, 29-37. [CrossRef]

21. Lu, J.; Ali, H.; Hurh, J.; Han, Y.; Batjikh, I.; Rupa, E.J.; Anandapadmanaban, G.; Park, J.K.; Yang, D.C. The assessment of photocatalytic activity of zinc oxide nanoparticles from the roots of Codonopsis lanceolata synthesized by one-pot green synthesis method. Optik 2019, 184, 82-89. [CrossRef]

22. Madhumitha, G.; Fowsiya, J.; Gupta, N.; Kumar, A.; Singh, M. Green synthesis, characterization and antifungal and photocatalytic activity of Pithecellobium dulce peel-mediated ZnO nanoparticles. J. Phys. Chem. Solids 2019, 127, 43-51. [CrossRef]

23. Heiland, G.; Mollwo, E.; Stöckmann, F. Electronic processes in zinc oxide. In Solid State Physics; Elsevier: Amsterdam, The Netherlands, 1959; pp. 191-323.

24. Samadi, M.; Zirak, M.; Naseri, A.; Khorashadizade, E.; Moshfegh, A.Z. Recent progress on doped ZnO nanostructures for visible-light photocatalysis. Thin Solid Film. 2016, 605, 2-19. [CrossRef]

25. Farooq, M.H.; Aslam, I.; Anam, H.S.; Tanveer, M.; Ali, Z.; Ghani, U.; Boddula, R. Improved photocatalytic performance of reduced zinc oxide $(\mathrm{ZnO})$ novel morphology of astray like microstructure under solar light irradiation. Mater. Sci. Energy Technol. 2019, 2 181-186. [CrossRef]

26. Kumari, V.; Mittal, A.; Jindal, J.; Yadav, S.; Kumar, N. S-, N-and C-doped ZnO as semiconductor photocatalysts: A review. Front. Mater. Sci. 2019, 13, 1-22. [CrossRef]

27. Wen, J.Q.; Chen, G.X.; Zhang, J.M.; Li, D.M.; Zhang, X.Z. Magnetic transition in nonmetal N-and F-doping g-ZnO monolayer with different concentrations. J. Supercond. Nov. Magn. 2018, 31, 3133-3139. [CrossRef]

28. Wang, J.; Lu, J.; Zhang, Q.; Yin, S.; Sato, T.; Saito, F. Mechanochemical doping of a non-metal element into zinc oxide. Chem. Sustain. Dev. 2007, 15, 249-253.

29. Ma, Z.; Ren, F.; Ming, X.; Long, Y.; Volinsky, A.A. Cu-doped ZnO electronic structure and optical properties studied by first-principles calculations and experiments. Materials 2019, 12, 196. [CrossRef] [PubMed]

30. Li, Q.; Zhu, L.; Li, Y.; Zhang, X.; Niu, W.; Guo, Y.; Ye, Z. Highly conductive thin films of nonmetal F and B co-doped ZnO on flexible substrates: Experiment and first-principles calculations. J. Alloy. Compd. 2017, 697, 156-160. [CrossRef]

31. Boonchun, A.; Lambrecht, W.R. Electronic structure of defects and doping in ZnO: Oxygen vacancy and nitrogen doping. Phys. Status Solidi (B) 2013, 250, 2091-2101. [CrossRef]

32. Byzynski, G.; Melo, C.; Volanti, D.P.; Ferrer, M.M.; Gouveia, A.F.; Ribeiro, C.; Andrés, J.; Longo, E. The interplay between morphology and photocatalytic activity in ZnO and N-doped ZnO crystals. Mater. Des. 2017, 120, 363-375. [CrossRef]

33. Oliveira, J.A.; Nogueira, A.E.; Goncalves, M.C.; Paris, E.C.; Ribeiro, C.; Poirier, G.Y.; Giraldi, T.R. Photoactivity of N-doped ZnO nanoparticles in oxidative and reductive reactions. Appl. Surf. Sci. 2018, 433, 879-886. [CrossRef]

34. Kumari, R.; Sahai, A.; Goswami, N. Effect of nitrogen doping on structural and optical properties of ZnO nanoparticles. Prog. Nat. Sci. Mater. Int. 2015, 25, 300-309. [CrossRef]

35. Soöllradl, S.; Greiwe, M.; Bukas, V.J.; Buchner, M.R.; Widenmeyer, M.; Kandemir, T.; Zweifel, T.; Senyshyn, A.; Guünther, S.; Nilges, T. Nitrogen-doping in ZnO via combustion synthesis? Chem. Mater. 2015, 27, 4188-4195. [CrossRef]

36. Zeuner, A.; Alves, H.; Sann, J.; Kriegseis, W.; Neumann, C.; Hofmann, D.; Meyer, B.; Hoffmann, A.; Haboeck, U.; Straßburg, M. Nitrogen doping in bulk and epitaxial ZnO. Phys. Status Solidi (C) 2004, 1, 731-734. [CrossRef]

37. Qiu, Y.; Yan, K.; Deng, H.; Yang, S. Secondary branching and nitrogen doping of ZnO nanotetrapods: Building a highly active network for photoelectrochemical water splitting. Nano Lett. 2012, 12, 407-413. [CrossRef]

38. Yu, Z.; Yin, L.-C.; Xie, Y.; Liu, G.; Ma, X.; Cheng, H.-M. Crystallinity-dependent substitutional nitrogen doping in ZnO and its improved visible light photocatalytic activity. J. Colloid Interface Sci. 2013, 400, 18-23. [CrossRef]

39. Balcha, A.; Yadav, O.P.; Dey, T. Photocatalytic degradation of methylene blue dye by zinc oxide nanoparticles obtained from precipitation and sol-gel methods. Environ. Sci. Pollut. Res. 2016, 23, 25485-25493. [CrossRef] 
40. Irani, M.; Mohammadi, T.; Mohebbi, S. Photocatalytic degradation of methylene blue with ZnO nanoparticles; a joint experimental and theoretical study. J. Mex. Chem. Soc. 2016, 60, 218-225. [CrossRef]

41. Shinde, D.R.; Tambade, P.S.; Chaskar, M.G.; Gadave, K.M. Photocatalytic degradation of dyes in water by analytical reagent grades $\mathrm{ZnO}, \mathrm{TiO}_{2}$ and $\mathrm{SnO}_{2}$ : A comparative study. Drink. Water Eng. Sci. 2017, 10, 109-117. [CrossRef]

42. Rakibuddin, M.; Ananthakrishnan, R. Novel nano coordination polymer based synthesis of porous ZnO hexagonal nanodisk for higher gas sorption and photocatalytic activities. Appl. Surf. Sci. 2016, 362, 265-273. [CrossRef]

43. Bora, T.; Sathe, P.; Laxman, K.; Dobretsov, S.; Dutta, J. Defect engineered visible light active ZnO nanorods for photocatalytic treatment of water. Catal. Today 2017, 284, 11-18. [CrossRef]

44. Yang, X.; Qiu, L.; Luo, X. ZIF-8 derived Ag-doped ZnO photocatalyst with enhanced photocatalytic activity. RSC Adv. 2018, 8, 4890-4894. [CrossRef]

45. Kumar, S.; Singh, V.; Tanwar, A. Structural, morphological, optical and photocatalytic properties of Ag-doped ZnO nanoparticles J. Mater. Sci. Mater. Electron. 2016, 27, 2166-2173. [CrossRef]

46. Ashebir, M.E.; Tesfamariam, G.M.; Nigussie, G.Y.; Gebreab, T.W. Structural, optical, and photocatalytic activities of Ag-doped and Mn-doped ZnO nanoparticles. J. Nanomater. 2018, 2018, 9425938. [CrossRef]

47. Vallejo, W.; Cantillo, A.; Díaz-Uribe, C. Methylene blue photodegradation under visible irradiation on Ag-Doped ZnO thin films Int. J. Photoenergy 2020, 2020, 1627498. [CrossRef]

48. Sabry, R.S.; Rahmah, M.I.; Aziz, W.J. A systematic study to evaluate effects of stearic acid on superhydrophobicity and photocatalytic properties of Ag-doped ZnO nanostructures. J. Mater. Sci. Mater. Electron. 2020, 31, 13382-13391. [CrossRef]

49. Liu, J.; Li, J.; Wei, F.; Zhao, X.; Su, Y.; Han, X. Ag-ZnO submicrometer rod arrays for high-efficiency photocatalytic degradation of Congo red and disinfection. ACS Sustain. Chem. Eng. 2019, 7, 11258-11266. [CrossRef]

50. Saffari, R.; Shariatinia, Z.; Jourshabani, M. Synthesis and photocatalytic degradation activities of phosphorus containing ZnO microparticles under visible light irradiation for water treatment applications. Environ. Pollut. 2020, 259, 113902. [CrossRef]

51. Kuriakose, S.; Satpati, B.; Mohapatra, S. Highly efficient photocatalytic degradation of organic dyes by Cu doped ZnO nanostructures. Phys. Chem. Chem. Phys. 2015, 17, 25172-25181. [CrossRef]

52. Vaiano, V.; Iervolino, G.; Rizzo, L. Cu-doped $\mathrm{ZnO}$ as efficient photocatalyst for the oxidation of arsenite to arsenate under visible light. Appl. Catal. B Environ. 2018, 238, 471-479. [CrossRef]

53. Chandekar, K.V.; Shkir, M.; Al-Shehri, B.M.; AlFaify, S.; Halor, R.G.; Khan, A.; Al-Namshah, K.S.; Hamdy, M.S. Visible light sensitive $\mathrm{Cu}$ doped $\mathrm{ZnO}$ : Facile synthesis, characterization and high photocatalytic response. Mater. Charact. 2020, 165, 110387. [CrossRef]

54. Etacheri, V.; Roshan, R.; Kumar, V. Mg-doped ZnO nanoparticles for efficient sunlight-driven photocatalysis. ACS Appl. Mater. Interfaces 2012, 4, 2717-2725. [CrossRef]

55. Adam, R.E.; Alnoor, H.; Pozina, G.; Liu, X.; Willander, M.; Nur, O. Synthesis of Mg-doped ZnO NPs via a chemical lowtemperature method and investigation of the efficient photocatalytic activity for the degradation of dyes under solar light. Solid State Sci. 2020, 99, 106053. [CrossRef]

56. Adeel, M.; Saeed, M.; Khan, I.; Muneer, M.; Akram, N. Synthesis and characterization of Co-ZnO and evaluation of its photocatalytic activity for photodegradation of methyl orange. ACS Omega 2021, 6, 1426-1435. [CrossRef]

57. Hernández-Carrillo, M.; Torres-Ricárdez, R.; García-Mendoza, M.; Ramírez-Morales, E.; Rojas-Blanco, L.; Díaz-Flores, L.; Sepúlveda-Palacios, G.; Paraguay-Delgado, F.; Pérez-Hernández, G. Eu-modified ZnO nanoparticles for applications in photocatalysis. Catal. Today 2020, 349, 191-197. [CrossRef]

58. Ahmad, I.; Akhtar, M.S.; Ahmed, E.; Ahmad, M.; Keller, V.; Khan, W.Q.; Khalid, N. Rare earth co-doped ZnO photocatalysts: Solution combustion synthesis and environmental applications. Sep. Purif. Technol. 2020, 237, 116328. [CrossRef]

59. Pascariu, P.; Tudose, I.V.; Suchea, M.; Koudoumas, E.; Fifere, N.; Airinei, A. Preparation and characterization of Ni, Co doped ZnO nanoparticles for photocatalytic applications. Appl. Surf. Sci. 2018, 448, 481-488. [CrossRef]

60. Shanmugam, V.; Jeyaperumal, K.S. Investigations of visible light driven $\mathrm{Sn}$ and $\mathrm{Cu}$ doped $\mathrm{ZnO}$ hybrid nanoparticles for photocatalytic performance and antibacterial activity. Appl. Surf. Sci. 2018, 449, 617-630. [CrossRef]

61. Qin, J.; Zhang, X.; Yang, C.; Cao, M.; Ma, M.; Liu, R. ZnO microspheres-reduced graphene oxide nanocomposite for photocatalytic degradation of methylene blue dye. Appl. Surf. Sci. 2017, 392, 196-203. [CrossRef]

62. Ullah, R.; Dutta, J. Photocatalytic degradation of organic dyes with manganese-doped ZnO nanoparticles. J. Hazard. Mater. 2008, 156, 194-200. [CrossRef]

63. Mohamed, R.; Shawky, A. CNT supported Mn-doped ZnO nanoparticles: Simple synthesis and improved photocatalytic activity for degradation of malachite green dye under visible light. Appl. Nanosci. 2018, 8, 1179-1188. [CrossRef]

64. Labhane, P.; Patle, L.; Sonawane, G.; Sonawane, S. Fabrication of ternary Mn doped ZnO nanoparticles grafted on reduced graphene oxide (RGO) sheet as an efficient solar light driven photocatalyst. Chem. Phys. Lett. 2018, 710, 70-77. [CrossRef]

65. Ghosh, M.; Manoli, K.; Shen, X.; Wang, J.; Ray, A.K. Solar photocatalytic degradation of caffeine with titanium dioxide and zinc oxide nanoparticles. J. Photochem. Photobiol. A Chem. 2019, 377, 1-7. [CrossRef]

66. Subhan, M.A.; Uddin, N.; Sarker, P.; Azad, A.K.; Begum, K. Photoluminescence, photocatalytic and antibacterial activities of $\mathrm{CeO} 2 \cdot \mathrm{CuO} \cdot \mathrm{ZnO}$ nanocomposite fabricated by co-precipitation method. Spectrochim. Acta Part A Mol. Biomol. Spectrosc. 2015, 149, 839-850. [CrossRef] [PubMed] 
67. Akhtar, J.; Tahir, M.; Sagir, M.; Bamufleh, H.S. Improved photocatalytic performance of Gd and Nd co-doped ZnO nanorods for the degradation of methylene blue. Ceram. Int. 2020, 46, 11955-11961. [CrossRef]

68. Arshad, M.; Qayyum, A.; Abbas, G.; Haider, R.; Iqbal, M.; Nazir, A. Influence of different solvents on portrayal and photocatalytic activity of tin-doped zinc oxide nanoparticles. J. Mol. Liq. 2018, 260, 272-278. [CrossRef]

69. Nguyen, L.T.; Nguyen, L.T.; Duong, A.T.; Nguyen, B.D.; Hai, N.Q.; Chu, V.H.; Nguyen, T.D.; Bach, L.G. Preparation, characterization and photocatalytic activity of La-doped zinc oxide nanoparticles. Materials 2019, 12, 1195. [CrossRef]

70. Babajani, N.; Jamshidi, S. Investigation of photocatalytic malachite green degradation by iridium doped zinc oxide nanoparticles: Application of response surface methodology. J. Alloy. Compd. 2019, 782, 533-544. [CrossRef]

71. Yousefi, R.; Jamali-Sheini, F.; Cheraghizade, M.; Khosravi-Gandomani, S.; Saáaedi, A.; Huang, N.M.; Basirun, W.J.; Azarang, M. Enhanced visible-light photocatalytic activity of strontium-doped zinc oxide nanoparticles. Mater. Sci. Semicond. Processing 2015 32, 152-159. [CrossRef]

72. Khezami, L.; Taha, K.K.; Ghiloufi, I.; El Mir, L. Adsorption and photocatalytic degradation of malachite green by vanadium doped zinc oxide nanoparticles. Water Sci. Technol. 2016, 73, 881-889. [CrossRef]

73. Goswami, M. Enhancement of photocatalytic activity of synthesized Cobalt doped Zinc Oxide nanoparticles under visible light irradiation. Opt. Mater. 2020, 109, 110400. [CrossRef]

74. Ebrahimi, R.; Hossienzadeh, K.; Maleki, A.; Ghanbari, R.; Rezaee, R.; Safari, M.; Shahmoradi, B.; Daraei, H.; Jafari, A.; Yetilmezsoy, $\mathrm{K}$. Effects of doping zinc oxide nanoparticles with transition metals $(\mathrm{Ag}, \mathrm{Cu}, \mathrm{Mn}$ ) on photocatalytic degradation of Direct Blue 15 dye under UV and visible light irradiation. J. Environ. Health Sci. Eng. 2019, 17, 479-492. [CrossRef] [PubMed]

75. Alshamsi, H.A.H.; Hussein, B.S. Hydrothermal Preparation of Silver Doping Zinc Oxide Nanoparticles: Study the Characterization and Photocatalytic Activity. Orient. J. Chem. 2018, 34, 1898. [CrossRef]

76. Saber, O.; El-Brolossy, T.A.; Al Jaafari, A.A. Improvement of photocatalytic degradation of naphthol green B under solar light using aluminum doping of zinc oxide nanoparticles. Water Air Soil Pollut. 2012, 223, 4615-4626. [CrossRef]

77. Zhang, J.; Deng, S.; Liu, S.; Chen, J.; Han, B.; Wang, Y.; Wang, Y. Preparation and photocatalytic activity of Nd doped ZnO nanoparticles. Mater. Technol. 2014, 29, 262-268. [CrossRef]

78. Ibrahim, M.M.; Asal, S. Physicochemical and photocatalytic studies of Ln3+-ZnO for water disinfection and wastewater treatment applications. J. Mol. Struct. 2017, 1149, 404-413. [CrossRef]

79. Yi, G.; Yuan, Y.; Li, X.; Zhang, Y. ZnO Nanopillar Coated Surfaces with Substrate-Dependent Superbactericidal Property. Small 2018, 14, 1703159. [CrossRef] [PubMed]

80. Rahman, A.H.; Misra, A.J.; Das, S.; Das, B.; Jayabalan, R.; Suar, M.; Mishra, A.; Tamhankar, A.J.; Lundborg, C.S.; Tripathy, S.K. Mechanistic insight into the disinfection of Salmonella sp. by sun-light assisted sonophotocatalysis using doped ZnO nanoparticles. Chem. Eng. J. 2018, 336, 476-488. [CrossRef]

81. Dimapilis, E.A.S.; Hsu, C.-S.; Mendoza, R.M.O.; Lu, M.-C. Zinc oxide nanoparticles for water disinfection. Sustain. Environ. Res. 2018, 28, 47-56. [CrossRef]

82. Sultana, K.A.; Islam, M.T.; Silva, J.A.; Turley, R.S.; Hernandez-Viezcas, J.A.; Gardea-Torresdey, J.L.; Noveron, J.C. Sustainable synthesis of zinc oxide nanoparticles for photocatalytic degradation of organic pollutant and generation of hydroxyl radical. $J$. Mol. Liq. 2020, 307, 112931. [CrossRef]

83. Rambabu, K.; Bharath, G.; Banat, F.; Show, P.L. Green synthesis of zinc oxide nanoparticles using Phoenix dactylifera waste as bioreductant for effective dye degradation and antibacterial performance in wastewater treatment. J. Hazard. Mater. 2021, 402, 123560. [CrossRef] [PubMed]

84. Phan, D.-N.; Rebia, R.A.; Saito, Y.; Kharaghani, D.; Khatri, M.; Tanaka, T.; Lee, H.; Kim, I.-S. Zinc oxide nanoparticles attached to polyacrylonitrile nanofibers with hinokitiol as gluing agent for synergistic antibacterial activities and effective dye removal. J. Ind. Eng. Chem. 2020, 85, 258-268. [CrossRef]

85. Gancheva, M.; Markova-Velichkova, M.; Atanasova, G.; Kovacheva, D.; Uzunov, I.; Cukeva, R. Design and photocatalytic activity of nanosized zinc oxides. Appl. Surf. Sci. 2016, 368, 258-266. [CrossRef]

86. Mahamuni, P.P.; Patil, P.M.; Dhanavade, M.J.; Badiger, M.V.; Shadija, P.G.; Lokhande, A.C.; Bohara, R.A. Synthesis and characterization of zinc oxide nanoparticles by using polyol chemistry for their antimicrobial and antibiofilm activity. Biochem. Biophys. Rep. 2019, 17, 71-80. [CrossRef] [PubMed]

87. Haque, M.J.; Bellah, M.M.; Hassan, M.R.; Rahman, S. Synthesis of ZnO nanoparticles by two different methods \& comparison of their structural, antibacterial, photocatalytic and optical properties. Nano Express 2020, 1, 010007.

88. Ogunyemi, S.O.; Abdallah, Y.; Zhang, M.; Fouad, H.; Hong, X.; Ibrahim, E.; Masum, M.M.I.; Hossain, A.; Mo, J.; Li, B. Green synthesis of zinc oxide nanoparticles using different plant extracts and their antibacterial activity against Xanthomonas oryzae pv. oryzae, Artificial cells. Nanomed. Biotechnol. 2019, 47, 341-352.

89. Suresh, J.; Pradheesh, G.; Alexramani, V.; Sundrarajan, M.; Hong, S.I. Green synthesis and characterization of zinc oxide nanoparticle using insulin plant (Costus pictus D. Don) and investigation of its antimicrobial as well as anticancer activities. Adv. Nat. Sci. Nanosci. Nanotechnol. 2018, 9, 015008. [CrossRef]

90. Panchal, P.; Paul, D.R.; Sharma, A.; Choudhary, P.; Meena, P.; Nehra, S. Biogenic mediated Ag/ZnO nanocomposites for photocatalytic and antibacterial activities towards disinfection of water. J. Colloid Interface Sci. 2020, 563, 370-380. [CrossRef] 
91. He, W.; Kim, H.-K.; Wamer, W.G.; Melka, D.; Callahan, J.H.; Yin, J.-J. Photogenerated charge carriers and reactive oxygen species in $\mathrm{ZnO} / \mathrm{Au}$ hybrid nanostructures with enhanced photocatalytic and antibacterial activity. J. Am. Chem. Soc. 2014, 136, 750-757. [CrossRef]

92. Qamar, M.A.; Shahid, S.; Javed, M.; Iqbal, S.; Sher, M.; Akbar, M.B. Highly efficient g-C3N4/Cr-ZnO nanocomposites with superior photocatalytic and antibacterial activity. J. Photochem. Photobiol. A Chem. 2020, 401, 112776. [CrossRef]

93. Munawar, T.; Yasmeen, S.; Hussain, A.; Akram, M.; Iqbal, F. Novel direct dual-Z-scheme ZnO-Er2O3-Yb2O3 heterostructured nanocomposite with superior photocatalytic and antibacterial activity. Mater. Lett. 2020, 264, 127357. [CrossRef]

94. Das, S.; Sinha, S.; Das, B.; Jayabalan, R.; Suar, M.; Mishra, A.; Tamhankar, A.J.; Lundborg, C.S.; Tripathy, S.K. Disinfection of multidrug resistant Escherichia coli by solar-photocatalysis using Fe-doped ZnO nanoparticles. Sci. Rep. 2017, 7, 1-14. [CrossRef] [PubMed]

95. Oquendo-Cruz, A.; Perales-Pérez, O. Synthesis, characterization and bactericide properties of pure and Li doped ZnO nanoparticles for alternative water disinfection methods. J. Electron. Mater. 2018, 47, 6260-6265. [CrossRef]

96. Darwish, A.S.; Bayaumy, F.E.; Ismail, H.M. Photoactivated water-disinfecting, and biological properties of Ag NPs@ Sm-doped $\mathrm{ZnO}$ nanorods/cuttlefish bone composite: In-vitro bactericidal, cercaricidal and schistosomicidal studies. Mater. Sci. Eng. C 2018, 93, 996-1011. [CrossRef] 